Hughes, 1977). In sapphirine sites which can become available for occupation by $\mathrm{Cr}^{3+}$ may be created by an $\mathrm{Al}^{3+}$ to $\mathrm{Cr}^{3+}$ substitution during the formation of the sapphirine.

This detailed mineralogical work on reaction rocks produced at the contact of the anorthosite complex provides corroborative evidence for conditions of high water vapour pressure during the crystallisation history of the Fiskenæsset anorthosite complex.

\title{
References
}

Friend, C. R. L. \& Hughes, D. J. 1977: Archaean aluminous ultrabasic rocks with primary igneous textures from the Fiskenæsset region, southern West Greenland. Earth planet. Sci. Lett. 36, 157-167. Ghisler, M. \& Windley, B. F. 1967: The chromite deposits of the Fiskenæsset region, West Greenland. Rapp. Grønlands geol. Unders. 12, $39 \mathrm{pp}$.

Higgins, J. B., Ribbe, P. H. \& Herd, R. K. 1979: Sapphirine 1. Crystal chemical contributions. Contr. Miner. Petr. 68, 349-356.

Leake, B. E. 1978: Nomenclature of amphiboles. Mineralog. Mag. 42, 553-563.

Shiraki, K. 1966: Some aspects of the geochemistry of chromium. J. Earth Sci. 14(1), 10-55.

Wager, L. R. \& Brown, G. M. 1968: Layered Igneous Rocks. Edinburgh \& London: Oliver \& Boyd. Windley, B. F., Herd, R. K. \& Bowden, A. A. 1973: The Fiskenæsset complex, West Greenland. Part I. A preliminary study of the stratigraphy, petrology and whole-rock chemistry from Qeqertarssuatsiaq. Bull. Grønlands geol. Unders. 106, 80 pp.

\section{Thorium-uranium mineralisation in the vicinity of the Igdlerfigssalik centre of the Igaliko Complex, South Greenland}

\section{Agnete Steenfelt and Tapani Tukiainen}

The existence of radioactive rocks in the area south of the Igdlerfigssalik centre of the Igaliko nepheline syenite complex has been known since 1962 (S. Andersen, personal communication). Reconnaissance radiometric investigations on the ground and from a helicopter in 1979 and 1980 revealed a large number of occurrences of radioactive mineralisation. The characteristics of the mineralisation are briefly described.

\section{Geology}

The area is underlain by the Proterozoic 'Julianehåb Granite' (1810-1770 m.y.; van Breemen et al., 1974) which during the Gardar period (1330-1150 m.y.; Emeleus \& Upton, 1976) was faulted and intruded by numerous ENE-trending dykes, and the emplacement of 


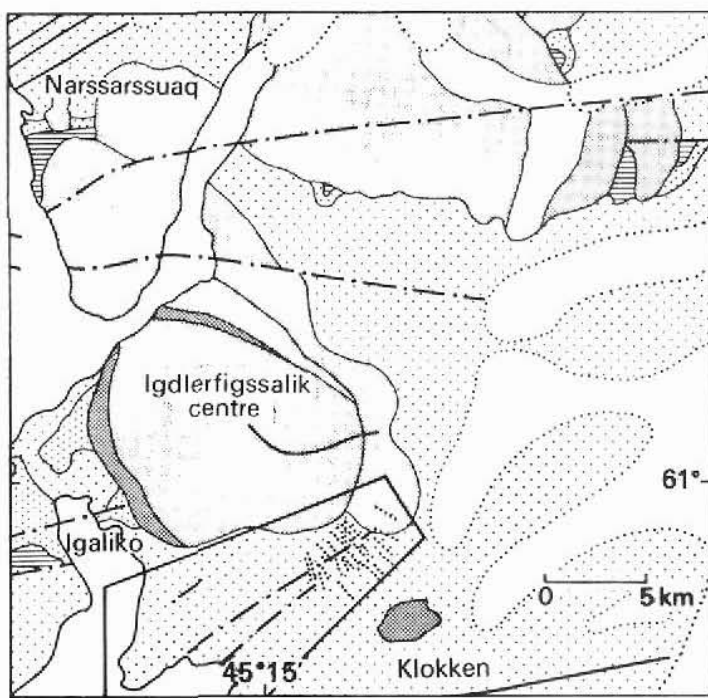

Gardar rocks

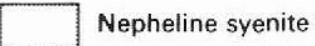

Augite syenite

Lavas

Sediments

Pre-Gardar granite

Dolerite dyke

- - Fault

Syenite dyke, joint enhanced and not to scale

Fig. 15. Simplified geological map of the Igaliko area, South Greenland (from Emeleus \& Upton, 1976). Structures containing Th-U mineralisation are shown in the outlined area.

the four central alkali syenite centres of the Igaliko complex. The Igdlerfigssalik centre is the youngest of the intrusive centres. Emeleus \& Harry (1970) established the following chronology for the major events in the area: (1) early Igdlerfigssalik syenite units, (2) mid-Gardar ENE-trending dykes, (3) carly faults trending N-S and NE-SW, (4) late Igdlerfigssalik syenite units (1167士11 m.y.; Blaxland et al., 1978), (5) minor NE-SW faulting, and (6) late Gardar dykes. A few subhorizontal sheets of alkali syenite bounded by the major ENE fractures (fig. 15), and also a number of $150^{\circ}-180^{\circ}$ striking dykes of pegmatitic to coarse-grained alkali syenite intersect the basement granite. The syenitic dykes and joints cut the mid-Gardar $60^{\circ}$-trending dykes but they are in turn dissected and disturbed by later $60^{\circ}$ movements. Their exact relation to the late Igdlerfigssalik syenite units is uncertain.

\section{Mineralisation}

Occurrences of $\mathrm{Th}-\mathrm{U}$ mineralisation are controlled by two sets of fractures, one striking east-north-east, approximately $60^{\circ}$, i.e. parallel to the main dyke and fault direction, and another less prominent set of $150^{\circ}-180^{\circ}$ fractures. The two most marked $60^{\circ}$ fracture zones are shown on the map in fig. 15.

The $60^{\circ}$-trending fractures are vertical or steeply dipping north-west. The degree of cataclasis varies from weak shearing and brecciation to strong mylonitisation. Fluorite and vein quartz, less commonly chlorite, amphiboles and carbonate veinlets occur in the matrix of the breccias. The fracture zones generally display slightly elevated radioactivity. High radioactivity occurs in small spots, or in zones several tens of metres long, and is mostly confined to highly brecciated or mylonitised rocks which are characterised by strong haematisation. 
Table 5. Gamma-radiation and uranium content of samples from the vicinity of the Igaliko Complex

\begin{tabular}{lccc}
\hline Host to mineralisation & $\begin{array}{c}\text { Background } \\
\mu \mathrm{R} / \mathrm{h}\end{array}$ & $\begin{array}{c}\text { Peak values } \\
\mu \mathrm{R} / \mathrm{h}\end{array}$ & $\begin{array}{c}\text { Analysed samples } \\
\text { range of U ppm }\end{array}$ \\
\hline Fault breccia, mylonite & 20 & $500-1000$ & $26-40$ \\
Quartz aegirine joint fillings & $20-40$ & $200-1000$ & $32-42$ \\
Fenitised granite & 15 & $500-1500$ & $13-165$ \\
Fractured syenite dykes & 10 & $500-1500$ & $5-49$ \\
\hline
\end{tabular}

Quartz-aegirine joint fillings, 0.5 to $5 \mathrm{~cm}$ wide, are quite common in the granite, and they usually display irregularly distributed elevated radioactivity. The radioactive joints have an east-north-east and less commonly a north-south strike.

The Th-U occurrences in the $150^{\circ}-180^{\circ}$ striking fractures are confined to the alkali syenite dykes and joints filled with alkali minerals. A few syenite dykes and joints close to the $60^{\circ}$-direction were also observed. The radioactivity is found in, or adjacent to, coarse-grained pegmatitic syenite dykes up to several metres wide, in medium-grained syenite dykes, often less than $0.5 \mathrm{~m}$ wide and in thin joints filled with dark micaceous minerals and aegirine.

The dykes are rich in feldspar and contain arfvedsonite and/or aegirine, sometimes minor eudialyte and sporadic quartz. They are often sheared and altered having a dark rusty brown colour.

The granite adjacent to the alkali syenite dykes is often impregnated by fluorite and displays Na-metasomatism (formation of albite and Na-pyroxene). Spots of high radioactivity are associated with the metasomatised granite.

The field measurements of the gamma radiation and the analyses of samples from the investigated area are summarised in Table 5. Semiquantitative gamma-spectrometer measurements of rock samples have shown that Th commonly dominates over U.

\section{Origin of mineralisation}

The mineralogy and orientation of the mineralised dykes indicate that they are related to the alkaline magmatic activity in the Igdlerfigssalik centre. They cut the ENE-trending mid-Gardar dykes and are consequently thought to be associated with the intrusion of late syenite units. The mineralisation in the dykes is associated with fractures and alteration, and must be epigenetic. The frequency of radioactive occurrences decreases away from the Igdlerfigssalik centre, and it therefore seems probable that the mineralising fluids transporting $T h$ and $U$ were derived during late to post-magmatic processes. The association of radioactivity with fluorite and $\mathrm{Na}$-rich minerals suggests that these fluids were rich in $\mathrm{Na}$ and F, which again would point towards an origin related to alkaline magmatism.

Radioactive mineralisation in ENE-trending structures is widespread throughout the entire Gardar province (Ivigtut area; Berthelsen \& Henriksen, 1975 and Narssaq peninsula; 
Hansen, 1968), and a possibility still exists that the mineralisation in the ENE-trending structures in the vicinity of the Igdlerfigssalik centre belongs to a more extensive Gardar mineralising event.

\section{Conclusions}

The occurrences of Th-U radioactive mineralisation which, wholly or in part, can be related to the neighbouring Igdlerfigssalik centre, are small and scattered; only those in the ENE-directed structures have dimensions of some interest. The available analyses indicate that the radioactivity is mostly due to thorium and the possibility of finding economic uranium-occurrences in this area is regarded as unlikely.

\section{References}

Berthelsen, A. \& Henriksen, N. 1975: Descriptive text to Geological map of Greenland 1:100 000, Ivigtut, 61 V. 1 Syd. Copenhagen: Grønlands geol. Unders. (also Meddr Grønland 185, 1) 210 pp.

Blaxland, A. B., van Breemen, O., Emeleus, C. H. \& Anderson, J. G. 1978: Age and origin of the major syenite centers in the Gardar province of south Greenland: Rb-Sr studies. Bull. geol. Soc. Amer. 89, 231-244.

Emeleus, C. H. \& Harry, W. T. 1970: The Igaliko nepheline syenite complex. General description. Bull. Gronlands geol. Unders. 85, $112 \mathrm{pp}$.

Emeleus, C. H. \& Upton, B. G. J. 1976: The Gardar period in southern Greenland. In Escher, A. \& Watt, W. S. (edit.) Geology of Greenland, 154-181. Copenhagen: Geol. Surv. Greenland.

Hansen, J. 1968: A study of radioactive veins containing rare earth minerals in the area surrounding the Ilímaussaq alkaline intrusion in South Greenland. Bull. Grønlands geol. Unders. 76 (also Meddr Gronland 181, 8) $47 \mathrm{pp}$.

Van Breemen, O., Aftalion, M. \& Allaart, J. H. 1974: Isotopic and geochronological studies on granites from the Ketilidian mobile belt of South Greenland. Bull. geol. Soc. Amer. 85, 403-412.

\section{Uranium-bearing metasediment and granite in the Tasermiut area, South Greenland}

\section{Bjarne Leth Nielsen and Tapani Tukiainen}

Regional exploration for uranium was carried out in South Greenland in 1979 and 1980. From the planning stage the area between the fjords Tasermiut and Søndre Sermilik (fig. 16) was considered a favourable target because uranium deposits from geological environments of similar age, structure and lithology are known, e.g. the Makkovik Bay area in Labrador (Gandhi et al., 1969; McMillan, 1976). The deposits sought were mainly pegmatitic or vein type deposits related to a Proterozoic unconformity (Nielsen, 1980). During the South 